\title{
The Handling of the Pandemic Covid 19 in the Consciousness of the Legal Community in Bali
}

\author{
Yogi Yasa Wedha ${ }^{1 *}$, Holy One Singadimedja ${ }^{2}$, Edy Nurcahyo ${ }^{3}$, Ahmad Rosidi ${ }^{4}$, Sara Ida \\ Magdalena A wi $^{5}$ \\ ${ }^{* 1}$ Faculty of law, Udayana University \\ Bali, Indonesia \\ ${ }^{2}$ Faculty of law, Universitas Singaperbangsa Karawang \\ Jawa Barat, Indonesia \\ ${ }^{3}$ Faculty of law, Universitas Muhammadiyah Buton \\ Sulawesi Tenggara, Indonesia \\ ${ }^{4}$ Faculty of law, Universitas Gunung Rinjani \\ Nusa Tenggara Barat, Indonesia \\ ${ }^{5}$ Faculty of law, Jayapura Cenderawasih University \\ Papua, Indonesia \\ *Corresponding Authors: \\ Email: yogie_wedha@yahoo.com
}

\begin{abstract}
Abstrak.
This study discusses the legal awareness of the people of Bali are influenced by local wisdom in the face of pendemi covid-19. The purpose of this study is to analyze the success of handling Covid-19 in Bali in conjunction with legal awareness/ social culture of the Balinese people. There are two issues to be discussed, first how the legal regulation of countermeasures and efforts to break the chain of plague Covid-19 in Bali. Second, whether the local genius and social culture that has been there and is inherent in the fabric of Balinese life is effectively help the success of the handling of the Covid-19 in Bali ?The Research method used is normative law research Method reviewing the written law from various aspects, the approach of legislation (statute approach), the historical approach (historical approach), and a conceptual approach (conseptual approuach) and comparative approach (comparative approach) with the writing of descriptive analytical. The results of the research show that the Law is used to direct it to the goal-the desired destination, and creates patterns of behavior of new/social change in line with one of the functions of law, namely the function of the law as a means of social change, or a means to engineer society (social engineering). Tri Hita Karana (THK) as a frame of local wisdom in Bali in the life of indigenous peoples has been attached is the local wisdom that are rooted from culture and the hindu religion be a guideline and reference by the public in Bali to act/ behave this affects the legal awareness of the public to remain obedient and loyal in lawless in the community.
\end{abstract}

Keywords: Covid 19, Legal Awareness and Legal Culture

\section{INTRODUCTION}

Corona virus Disease 2019 (COVID-19) is a new disease that can cause respiratory disorders and pulmonary inflammation. The clinical symptoms vary, ranging from as common cold symptoms such as cough, runny nose, painful throat, muscle pain, pain of the head until the berkomplikasi severe pneumonia or sepsis. Plague Covid-19 Since its the first time that at the end of December 2019 in Wuhan China caused by the corona virus has very quickly spread to various countries in the world, the Data updates based on the source of the Word Healtth Organization (WHO), worldometer.info the UN Population Division of the since its appearance up to date last tertangggal May 24, 2020 the fact already as many as 216 countries in the world exposed covid-19 and the number of people of the world who are exposed to has more than five million people, this state of panic the population of the world due not only to the number of deaths caused, also the socio-economic impact in the future. Data dissemination Covid-19 in the World can be seen in the following table: 
Update Exposed Covid-19 in the World Update Tanggal 24 Mei 2020

\begin{tabular}{|l|l|c|c|l|c|}
\hline No & \multicolumn{1}{|c|}{ State } & Total Cases & Died & $\begin{array}{c}\text { Number Of } \\
\text { Inhabitants }\end{array}$ & $\begin{array}{c}\text { Death/ } \\
\text { 1jt population }\end{array}$ \\
\hline 1 & Amerika serikat & 1.547 .973 & 92.923 & 331.002 .651 & 281 \\
\hline 2 & Rusia & 335.882 & 3.388 & 145.934 .462 & 23 \\
\hline 3 & Brazil & 310.087 & 20.047 & 212.559 .417 & 94 \\
\hline 4 & Inggris & 254.199 & 36.393 & 67.886 .011 & 536 \\
\hline 5 & Spanyol & 234.824 & 28.628 & 46.754 .778 & 612 \\
\hline 6 & Italia & 228.658 & 32.616 & 60.461 .826 & 539 \\
\hline. & $\ldots \ldots$. & $\ldots \ldots$ & $\ldots .$. & $\ldots \ldots$ & $\ldots$ \\
\hline $\mathbf{3 1}$ & Indonesia & $\mathbf{2 2 . 4 7 1}$ & $\mathbf{1 . 3 7 2}$ & $\mathbf{2 6 9 . 6 0 3 . 4 0 0}$ & $\mathbf{5}$ \\
\hline & The World & $\mathbf{5 . 1 0 5 . 8 8 1}$ & $\mathbf{3 3 3 . 4 4 6}$ & $\mathbf{7 . 7 9 4 . 7 9 8 . 7 3 9}$ & $\mathbf{4 3}$ \\
\hline
\end{tabular}

source: Health Organitation (WHO), worldometer.info, UN populasi Divisi, BPS[1].

Given the spread of COVID-19 sporadic, uncontrolled and globally, then the world health Organization Word Healtth Organization (WHO) declared the outbreak COVID-19 as a global pandemic [2]. To provide protection for its citizens while controlling against the spread of the plague COVID-19 Government in various countries have taken the necessary actions to reduce the spread of COVID-19. Action-the action was tailored on the number of cases and the conditions in the country such as dismissed workers, schools, restrictions on various activities, require the use of masks and even some countries impose a lockdown.

Plague wirus COVID-19 spread so rapidly, the data spread in Indonesia updated May 24, 2020 known to have spread in 34 Provinces and 404 Districts/Cities in Indonesia. Of the total population of Indonesia as much as 269.603 .400 people, the Number exposed as much as 22.471 people, deaths from Covid-19 as many as 1372 is people. The government has made various efforts to control. Is an obligation of State/Government to attend to give protection to its people, given the spread of COVID-19 with the number of cases and/or the number of deaths is increasing and widespread cross-region and cross the country not only have an impact on public health, but also impact on aspects of political, economic, social, cultural, defense and security, as well as the welfare of the community. For that the Government of Indonesia has issued several regulations to address the problems Covid -19 Bali as one of the provinces affected by the outbreak Covid-19, that rely on tourism as a local revenue as well as the livelihood of the people, of pendemi Covid-19 give a bad impact for tourism in Bali. Local governments struggling to provide protection to public health, also dealing against the uprooting of the tourism business in Bali. Data as of May 24, 2020, in the Province of Bali Number of cumulative patients positive Covid-19 as many as 394 people, the number of patients who have been cured a number of 293 people, the number of patients who died a number of 4 people and the number of positive patients in care (active cases) 97 people. The Data shows that of the total population in Bali as much as 4,22 million, the number of cases COVID-19 by $1.7 \%$ the amount is relatively small considering Bali as a tourist destination of the world when the plague covid-19 occurred, there are still many tourists both foreign countries and domistik who come to Bali therefore estimated to Bali's potential as one of the epicenter of the spread of Covid-19. But in fact, the spread of the Plague Covid-19 not for sporadic spread in Bali, including still in the category of small when compared with other provinces in Indonesia fact it would be interesting to study from a variety of disciplines. Some media give an appreciation of handling covid19 in Bali, including the appreciation of the Inodesian President Mr. Joko Widodo [3].

The strategic step taken by the Governor of Bali, as efforts to accelerate the handling of COVID-19, either in the form of the issuance of the circular letter, rules to on involving Indigenous Villages to prevent and break the chain of spread of Covid-19 is considered to have been appropriate and provide a significant impact. That success in handling Covid-19 of course not only based on the support regulations/laws that have been published, because the fact is that the culture of the society (social culture) also strongly affect the enforceability of regulations/law, as delivered Satjipto Raharjo that talk about the law is talking about human relationships [4]. The relationship between man and that which creates law that in the end the law becomes a means to manage the order of life together in safeguarding the rights and obligations of individuals in society. The culture of law in society is 
closely related to the values, thoughts, as well as the expectations of the rules or norms in the social life of the community [5]. The community worker is closely linked to the Concept of Tri Hita Karana (THK) as a philosophy that is able to provide benefits for the life of the society, especially in terms of maintaining the principles of togetherness, harmony and balance. Tri hita karana is a local genius/wisdom of the local people of Bali that are rooted from the teachings of Hinduism, is an important concept that affects the relationship between the human and ultimately affect the social culture in the life of the indigenous peoples in Bali.

From the description above, the author interested to make a study about how social curture is influential on the success of Bali in prevent and break the chain of spread Covid-19 in Bali. With the focus of the study is about how the legal regulation of countermeasures and efforts to break the chain of plague Covid-19 in Bali? then also discussed about whether the local genius and social culture that has been there and is inherent in the fabric of Balinese life is effectively help the success of the handling of the Covid - 19 in Bali?

\section{RESEARCH METHODS}

Types of legal research using the object in the form of legal norms is done through the process of finding the rule of law, legal principles, and doctrines of law in order to answer the legal issues faced by [6]. As a type of normative legal research (normative law research), namely legal research that examines the written law from various aspects, including aspects of theory, history, philosophy and comparative. Research approaches in normative which is the approach of legislation (statute approach), the historical approach (historical approach), and a conceptual approach (conseptual approuach) [7]. The source of the material law in the legal research literature that legal research is done by researching library materials [8]. Focuses on the study of literature or also called as library research (library research), legal materials used in this study can be in the form of primary legal materials, secondary legal materials and tertiary legal materials. Material law is used to assess the existing problems. The object of this research in the form of analysis and study about the efforts of the provincial government of Bali conduct the handling of the prevention of the plague Covid-19 in Bali as well as study of the local genius and social culture that is inherent in the life of the people of Bali have contributed to the success of the handling Covid - 19 in Bali.

\section{RESULTS AND DISCUSSION}

\section{a. The Legal regulation of Penggendalian and the Handling of the Outbreak Covid-19 in Bali}

As the outbreak which has been declared pandemic by the WHO then both central and local government immediately take steps fast, precise, focused, integrated, and synergistic between ministries/agencies and local governments. The Provincial government of Bali has taken a strategic Step as the efforts to accelerate the handling of corona virus disease in 2019 (COVID-19), Legal Measures such as ;Menerbitkan Surat Himbauan Gubernur Bali No 45/Satgascovid19/III/2020 tanggal 27 Maret 2020.

1. Instructions the Governor About the Series of the Day of Nyepi Tahun Caka 1942.

2. The decision of the Governor BaliNo 273/04-G/HK/2020 On the Establishment of the Cluster Acceleration Handling the Impact and Recovery Due to the COVID-19 in the Province of Bali.

3. A joint decision between the Governor and Assembly of the Indigenous Village of Bali Province on the Establishment of a Task force Mutual Aid the Prevention of Covid-19 Village-based Customs.

4. Circular letter No. 109252020 about Control of the People Travel In the Entrance Region of Bali and the Acceleration of the Handling of the Covid-19.

In addition to publishing some of the regulations, To support the entire reduction activities Covid-19, the Governor of Bali has also been doing the reallocation and refocusing of a good budget for health care, handling the impact of the economy and to the social safety net. Products law was published in essence intended to provide protection to the public because one of the tasks and objectives of the Unitary State of the Republic of Indonesia is to protect the whole Indonesian nation and to promote the general welfare [9]. Appeal Phisical distancing, Social Distancing including Work From Home, use of masks and live a healthy life is the most important part. The Local government, all citizens of the community, traditional leaders, religious leaders, youth leaders, political figures, 
and all elements of society unite to strengthen discipline in the application of the protocol the prevention COVID-19 for more discipline and adherence to the provisions of the law, especially in the implementation of the prevention of the spread rate COVID-19 can certainly stop.

The function of the law as a tool to realize the security and order (rust en order) and is seen also as a tool of social engineering (tool of social engineering) in order to towards the social welfare. Roscoe Pound adheres to the flow theory of law modern sociological jurisprudence which states that, the legal process is essentially a process of social engineering (social engineering). That law is essentially a means that can be used to control and manipulate society. The law was necessary because in this life there are many interests to be protected. There are a number of social interests that can be protected through religious, moral and aesthetic and the form of other protection [10].

The function of the law, is to protect the interests of such common interests, social interests and personal interests [11]. The law is seen as one of the important aspects in society in order to realize the formation of the society that is orderly, comfortable full of peace. Changes in law can affect social change, in line with one of the functions of law, namely the function of the law as a means of social change or a means of engineering society (social engineering)[12]. In the legal system are advanced, the formation and development of the law is designed in a professional and logical, therefore, there is no doubt that the products the law can influence, even change the joints of the life of the community [13]. Any changes desired should remain over the need/the will of the community, the faster the law responds to change/ update the laws in a society then the sooner the role played the law to make changes to that community [14]. Law as a tool of social engineering can also be interpreted as a means intended to change the behavior of citizens, in accordance with the objectives that have been established previously [15].

In the handling of cases Covid-19, the authors agree with the opinion of the roscow pounds because based on the public interest and for the sake of people's safety should come first, then the State must be present and quick to act, make regulations used as a basis for legal action in protecting the public, also provide guidance and direction to the society towards a form of which has been determined or the law used to do social engineering of society to a goal which is expected.

Legal compliance is essentially the awareness and loyalty of the people to the law which applies as a rule (rule of the game) as a consequence of living together. Legal compliance the community will affect the community Awareness of the law. People obey the law because they are indeed his soul is aware that they need a law and believes that the law was aimed at better and have set the community in a good, right and fair. Therefore, to arrange to live together humanly, it is not enough just based on the rule of law set by the institution authorities /the Law of Positive, but also stay lean on awareness prapositif of the law of nature [16].

\section{b. The existence of the Social Culture of Indigenous Peoples in Bali in Prevent and Break the Chain of Spread Covid-19}

Wayan Koster as the Governor of Bali and confirms that the focus handling of cases Covid-19 in Bali is an attempt to restrain the rate of increase of positive patients, so that when it appears the case Covid-19 in Bali, the Provincial government immediately issued a joint decision of the Assembly of the Customary Village and the Parisada Hindu Dharma Indonesia (PHDI) of Bali Province to form a task Force Mutual Aid Based on Customary Village. Traditional village become the main pillar for maintaining at the same time disciplining the community, using customary laws, to public order and discipline and simultaneously to control the movement of the community. The formation of a task force mutual aid of village-based customary form post mutual cooperation in all the villages of customs to control entry and exit of people to the traditional village environment respectively. Involving the traditional village as the tip of the spear handling covid-19 because of the existence of the desa adat in Bali is very strong.

People in Bali in general are very submissive and obedient to the customary law that grows, lives and develops in society, in addition desa adat in Bali is autonomous, can set itself, has a security system of its own, namely pelancang. The existence of indigenous Villages in the prevention Covid19, in addition based on various regulations issued by the Government, the strengthening of the implementation of the handling of the Covid-19, Desa Adat is also published Perarem (Customs Regulations) to bind citizens to obedience to the provisions that have been made, as has been done by the Traditional Village Sanur, Denpasar City and the traditional Village of Tanjung Bungkak [17]. 
With the spirit of ngayah with sincerity, prajuru traditional village and pecalang as a keeper of traditional values and the security of the socialization activities of the home-house, in the neighborhood of the village. This activity gives the result not the development in the masiv and sporadic outbreaks pendemi Covid-19 in Bali. Management efforts involving indigenous peoples has been appreciated by President Jokowi. The success of patterns of treatment and prevention through the empowerment of indigenous villages and is based on the local wisdom there is to be an important part recognized the truth by Gubernir Bali.

That the existence of customary law in Indonesia until now this has been recognized constitutionally. As stated in Article 18B paragraph (2) of the Act of 1945 which states that "the State recognizes and respects the unity of customary law communities with their traditional rights along still alive and in accordance with the development and the principle of the Unitary State of the Republic of Indonesia regulated in the law". Furthermore, in Article 28I paragraph (3) of the Act of 1945 stated that the cultural identities and rights of traditional communities be respected in harmony with the development of time and civilization. In Bali the Existence of an indigenous village in addition to remain alive, grow and develop in society, its existence in positive law has been regulated in the local REGULATION of Bali Province No. 4 Year 2019 about Village Customs.

Customary law in practice is to contain the wisdom-kearian local existence has been proved to be useful as an approach in various aspects of life. A formal judicial local knowledge has been introduced in Article 1 paragraph (30) of Law Number 32 year 2009 which states that local wisdom is a noble values applicable in the life of the community to, among others, protect and manage the environment sustainably. In that act also introduced the principle of local wisdom in environmental management in Indonesia, namely, that in the efforts of environmental protection and management should pay attention to the noble values applicable in the life of the community [18].

Local wisdom is the values, norms, laws and knowledge that is shaped by religious teachings, beliefs, values, traditional and experiences passed down by the ancestors that eventually form a system of local knowledge used to solve problems of day-to-day by the community [19]. The people of Bali with the Balinese culture which is imbued by the ideology of the Tri Hita Karana (THK) as the local advantages and local wisdom (indigenous wisdom) is unique, entrenched and institutionalized in the fabric of the lives of indigenous villagers. The ideology of THK is an integration of systemic of the concept of cucupu beads or the concept of the contents and the container. Ties the harmony between content and container is a condition of the realization of balance and happiness. The concept of cucupu beads confirms the presence of dynamics in life to always mutually adjust to changes, as an ideology of holistic, integral, and systemic [20]. THK uphold the values of balance and harmony between humans and God (parhyangan), the harmony of fellow human beings (pawongan), and the harmony of human being with environment (palemahan). Philosophy of THK has important values in supporting the success of the Balinese in dealing with the Covid - 19. A form of implementation that is: The obedience of the people of Bali to always follow the directives of the Assembly of Indigenous Villages in Bali through the bendesa adat and prajuru indigenous indigenous people simultaneously prayed and it with the aim that the given the strength to face the plague covid-19 and requested that this outbreak ends soon, is a manifestation of the Balinese People always uphold the values of balance and harmony between humans and God (parhyangan) which is rooted in the Hindu Religion Hindu.

1. Follow in an orderly appeal/circulars of the Government together with the Assembly of the Village Customs relating to the procedures for the implementation of Nyepi in setting the implementation of melasti and means pengerupukan, the ogoh-ogoh in the pendemi Covid-19, carrying out physical distancing and social distancing make adjustments to the implementation of traditional ceremony and religious, keep the flow out of the territory of the Village the Custom is one form of obedience in always keeping the harmony of the relations of fellow human beings (pawongan).

2. Maintain the harmony of human being with environment (palemahan) is performed by performing mutual cooperation ngayah to maintain the cleanliness of the environment, carry out spraying disinfectant in the Village. guard the entrance and the supervision of people that enter/exit the Village.

Behavior always in the foreground to the background by obedience to the ideology/philosophy of THK is inherent and manifest in the order of the day-to-day lives of Indigenous peoples as a buffer to Bali on various onslaught in the midst of globalization. Cultural identity is very strong integrated in the life of an Indigenous Village in addition to as a fortress of defense, also is the driving engine of 
cultural as well as filter acculturation of foreign culture. In conjunction with the pandemic Covid-19 this, in addition to the efforts as have been applied by both the Government and the WHO, specifically in Bali Traditional Village has also become the tip of the spear to keep the discipline of the community. Can not be ignored one of the factors that affect the adherence to law in society is the wisdom of the local communities which formed from the social interactions and ultimately shaping legal awareness and compliance of the community itself. As the opinion of the legal theory of history, Von Savigny stated that every nation has what is called Volggeist (the Soul of a Nation) who incarnated in the language, the customs, the arrangement state of the nation and also in the law. The law was in the consciousness of the nation, so the consciousness of the nation that becomes the base and the seat of the law [21].

The factor of legal awareness is very plays an important role in the development of the law that the weaker the level of public awareness, the weaker the compliance of the law on the contrary, the strong consciousness of the ruling, the stronger the factor of compliance of the law. Awareness of the law and not the views of living in the community about what the law was. View-the view of life in society is not solely a product of considerations according to the sense alone, but develops under the influence of several factors such as religion, economy, politics and so forth.

The author argues that the level of awareness of the law and obedience to the law of the Balinese people against the customary law and positive law which applies strongly influenced by the order of life in indigenous communities which live, grow, develop and be recognized/obeyed by the community.

\section{CONCLUTION}

The law is not only used to establish patterns of habit and behavior that are in the community, but also to direct it to the goals he desired, and create patterns of behaviour of new/social change in line with one of the functions of law, namely the function of the law as a means of social change, or a means to engineer society (social engineering). Society to be orderly and comply with the law because $\mathrm{He}$ is confident that the law will protect him when He was right.

Local wisdom is an entity that largely determines the dignity of the human person in his community, as a truth that has been related or consistent, Tri Hita Karana (THK) as a frame of local wisdom in Bali in the life of indigenous peoples has been attached is the local wisdom that are rooted from culture and the Hindu religion be a guideline and reference by the public in Bali to act/ behave this affects the legal awareness and awareness of the law of causality and the understanding of the relationship which is symbiotic mutualistis.

\section{REFERENCE}

[1] Gugus Tugas Percepatan Penanganan COVID-19, Info Grafis COVID-19 (24 Mei 2020) Available From https://covid19.go.id/p/berita/infografis-covid-19-24-mei-2020 (Diakses 24 Mei 2020).

[2] Rizal Setyo Nugroho, 2020. Apa Itu Pandemi Global seperti yang dinyatakan WHO pada Covid19. Available From Kompas.com https://www.kompas.com/tren/read/2020/03/12/060100465/apa-itu-pandemi-globalseperti-yang-dinyatakan-who-pada-covid-19?page=2. (Diakses 24 Mei 2020).

[3] Desa adat di Bali berjibaku tangani covid \& pecalang jadi tenaga relawan sejati hingga dipuji Jokowi, https://bali.tribunnews.com/2020/05/18/desa-adat-di-bali-berjibaku-tanganicovid-pecalang-jadi-tenaga-relawan-sejati-hingga-dipuji-jokowi diakses tanggal 24 Mei 2020.

[4] Satjipto Raharjo, 2006. Ilmu Hukum. Cet. VI, Citra Aditya Bakti, Bandung h.159.

[5] Iman Pasu Marganda Hadiarto Purba, 2017. Penguatan budaya hukum masyarakat untuk menghasilkan kewarganegaraan transformative. Jurnal Civics Volume 14 Nomor 2, Oktober 2017, Universitas Negeri Surabaya. h.146-147.

[6] Peter Mahmud Marzuki 2008, Penelitian Hukum, Prenada Media Group, Jakarta, h.35

[7] Peter Mahmud Marzuki 2008, Penelitian Hukum, Prenada Media Group, Jakarta, h.93

[8] Soerjono Soekanto dan Sri Mamudji, 2011, Penelitian Hukum Normatif, Rajawali Pers, Jakarta. h. 1314. 
[9] Alinea ke-empat Undang-Undang Dasar Negara Republik Indonesia 1945

[10] Hari Chand, 2005. Modern Jurisprudence, Petaling Jaya, International law book Services h.195 , dalam Khazanah; Atip Latipulhayat, Roscow Pound, Padjadjaran Jurnal Ilmu Hukum, Volume 1- No 2 tahun 2014.

[11] Lili Rasjididan I.B. Wyasa Putra, 2003, Hukum Sebagai Suatu Sistem, Penerbit Mandar Maju, Bandung. h.123 .

[12] Munir Fuady, 2011. Sosiologi Hukum Kontemporer "Interaksi Hukum, Kekuasaan, dan Masyarakat", Kencana, Jakarta, h. 61.

[13] Munir Fuady, 2011. Sosiologi Hukum Kontemporer "Interaksi Hukum, Kekuasaan, dan Masyarakat", Kencana, Jakarta, h. 61.

[14] Nazaruddin Lathif, 2017. Teori Hukum sebagai Sarana/Alat Untuk Memperbaharui atau Merekayasa Masyarakat, Jurnal Pakuan Law Review Volume 3, Nomor 1, Januari- Juni 2017 Fak. Hukum Universitas Pakuan. h. 75.

[15] Lili Rasjidi, Ira Thania Rasjidi, 2007, Pengantar Filsafat Hukum, Mandar Maju, PT. Citra Aditya Bakti, Bandung, 2007, h 74.

[16] Nobertus Jegalus, 2011. Hukum Kata Kerja, Diskursus Filsafat Tentang Hukum Progresif Penerbit Obor, Jakarta, h.30-31.

[17] I Wayan Sui Suadnyana dan Ady Sucipto, 2020. Desa Adat di Bali Berjibaku Tangani Covid \& Pecalang Jadi Tenaga Relawan Sejati Hingga Dipuji Jokowi, https:/ / bali.tribunnews.com/2020/05/18/desa-adat-di-bali-berjibaku-tangani-covidpecalang-jadi-tenaga-relawan-sejati-hingga-dipuji-jokowi?page $=2$. diakses Tanggal 24 Mei 2020.

[18] Hendra Wahanu Prabandan, 2011 . Pembangunan Hukum Berbasis Kearifan Lokal, JDIH Bappenas Edisi 01/tahun XVII/2011. http://jdih.bappenas.go.id/data/file/ Pembangunan_Hukum_Berbasis_Kearifan_Lokal.pdf. diakses Tanggal 25 Mei 2020.

[19] Hendra Wahanu Prabandan, 2011 . Pembangunan Hukum Berbasis Kearifan Lokal, JDIH Bappenas Edisi 01/tahun XVII/2011. http://jdih.bappenas.go.id/data/file/ Pembangunan_Hukum_Berbasis_Kearifan_Lokal.pdf. diakses Tanggal 25 Mei 2020.

[20] Agastia, I.B.G. 2007. Mengkritisi Impelemtasi Tri Hita Karana. Warta Hindu Dharma, h. 40.

[21] Loc.cit Hukum Kata Kerja, Nubertus Jelagus. h.48. 